\title{
Nutrient limitation of phytoplankton in five impoundments on the Manyame River, Zimbabwe
}

\author{
Pamela Tendaupenyu* \\ University of Zimbabwe, Biological Sciences Department, PO Box M.P 167, Mount Pleasant, Harare, Zimbabwe
}

\begin{abstract}
Nutrient limitation was investigated in the Manyame lakes, namely, Harava Dam, Seke Dam, Lake Chivero, Lake Manyame and Bhiri Dam, during 2004-05. Selenestrum capricornutum was used as the test organism in one group of bioassays and the lakes' natural phytoplankton population in the other. Nitrogen was indicated to be the primary limiting nutrient in Harava Dam, Seke Dam and Lake Manyame. Phosphorus was found to be the primary limiting nutrient in Bhiri Dam while no nutrient was indicated to be limiting the growth of phytoplankton in Lake Chivero; instead, light was implicated to be limiting the growth of phytoplankton. Harava Dam and Seke Dam showed signs of enrichment, relative to 1977, attributed to sewage discharge from expanding urban settlements in Ruwa and surrounding areas. Lake Chivero has remained much the same in the last 30 years and was indicated to be acting as a nutrient trap, since the dams downstream of it were not found to be as eutrophic. Lake Manyame, Seke Dam and Harava Dam were concluded to be mesotrophic, Bhiri Dam oligotrophic and Lake Chivero eutrophic.
\end{abstract}

Keywords: bioassays, phytoplankton, nutrient limitation, eutrophication

\section{Introduction}

The availability of nutrients is a major limitation to aquatic primary productivity, especially of surface waters (Schindler, 1977). Phytoplankton plays an important part in material circulation and energy flow in aquatic ecosystems and also controls the growth, reproductive capacity and population dynamics of other aquatic organisms such as zooplankton and fish (Kuang et al., 2004). The ability to identify the factors that limit algal growth is of considerable importance to an understanding of the ecology of aquatic plants and to the development of effective water management practices (Beardall et al., 2001).

Most aquatic ecosystems around the world, especially rivers, lakes and reservoirs, have been polluted by untreated domestic sewage, domestic wastewater, industrial wastewater, agricultural waste, and other pollutants (Kuang et al., 2004). The addition of nutrients from these sources increases the biomass of aquatic plants, benthic invertebrates, and fish, as well as changing the taxonomic composition of these communities (Schindler et al., 1971). A reduction in habitat complexity and biodiversity has been observed in such water bodies (Vollenweider, 1992).

In general, throughout the world, phosphorus is the primary limiting nutrient in inland waters (Guildford et al., 2003) and this is the case in most Zimbabwean reservoirs except for those that have been artificially enriched. Robarts and Southall (1977) noted that phytoplankton growth in Zimbabwean manmade lakes was controlled by phosphorus and nitrogen to the degree of cultural eutrophication. Increasing the levels of phosphorus and nitrogen led to an increased growth rate of phytoplankton, and in cases where a continued increase in these nutrients did not increase phytoplankton growth rates, light was found to be the limiting factor. A similar observation was made in South

* To whom all correspondence should be addressed.

调 +263772348648/+2634333 334;

e-mail: pamelasibanda@yahoo.co.uk/psibanda@science.uz.ac.zw Received 8 February 2011; accepted in revised form 14 December 2011.
Africa by Haarhoff et. al. (1992), who reported that phosphorus was usually limiting in oligotrophic to mesotrophic systems, while nitrogen is only limiting in eutrophic systems, where effluents are a major source of nutrient load. Thornton (1980) reported that nitrogen and phosphorus were the most important limiting nutrients in Zimbabwean waters. Nutrient enrichment studies done in Lake Victoria and Lake Malawi showed that phytoplankton was limited by nitrogen, provided there was adequate light, in both lakes (Guildford et al., 2003). Studies on nutrient limitation in tropical areas are of importance as they determine the factors that control algal growth and the ones which threaten lakes that are still in a relatively unpolluted state.

The role of nutrients in the eutrophication of temperate lakes in the southern hemisphere has been evaluated in studies of a variety of lakes and reservoirs in New Zealand, Australia and South Africa. In general, the lakes in New Zealand have low total nitrogen to total phosphorus ratios and have about half the nitrogen concentration of comparable lakes in North America and Europe (UNEP, 2000). Lakes and reservoirs located in the semi-arid regions of South Africa and Australia tend to be phosphorus-limited to a greater extent than lakes and reservoirs located in the semi-arid south-west United States. Impoundments with low nutrient concentrations were usually phosphorus-limited, and, as phosphorus loading increased, nitrogen limitation became more pronounced (UNEP, 2000).

Systematic evaluation of the role of nutrient limitation in tropical lakes is not possible because too few of the wide variety of tropical lakes have been examined. East African lakes have received relatively more attention than the other lakes. Nitrogen limitation may be widespread because of the low nitrate concentration and moderate to high phosphate concentrations common in east African lakes (UNEP, 2003). In Ssouth American tropical floodplain lakes, seasonal and regional differences in the relative importance of nitrogen and phosphorus occur. Concentrations of both total nitrogen and total phosphorus in South American reservoirs correlate with chlorophyll (UNEP, 2000).

The purpose of this investigation was to determine the limiting nutrients in 5 impoundments on the Manyame River 


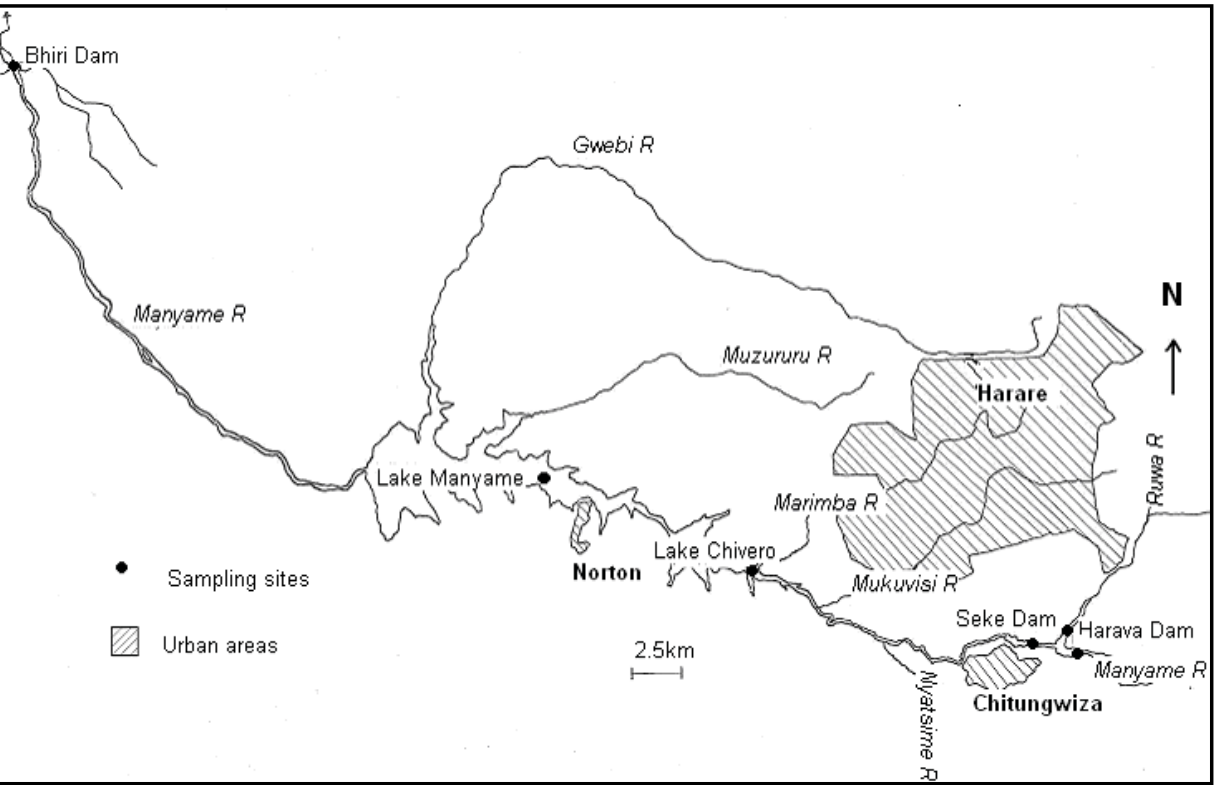

in Zimbabwe. Harava Dam, Seke Dam and Lake Chivero have been investigated previously by Robarts and Southall (1977) and are subject to increasing nutrient enrichment from the city of Harare, In the 1977 study by Robarts and Southall, phosphorus was found to be limiting in Harava and Seke Dams while no nutrient was found to be limiting the growth of phytoplankton in Lake Chivero; hence, light was concluded to be the limiting factor. This study provided an opportunity to determine whether or not phytoplankton is still limited by the same nutrients as it was almost 30 years ago in the 3 dams previously studied by Robarts and Southall (1977) and provides elementary information on nutrient limitation in Lake Manyame and Bhiri Dam, where not much work has previously been done. The research questions addressed in this investigation were: (i) what is the limiting nutrient in each dam; (ii) what is the phytoplankton composition and biomass in each dam; and (iii) is there any evidence that the previously oligotrophic impoundments have become enriched as a result of urban growth in their catchments?

\section{The study area}

The Manyame River, which rises near the town of Marondera about $65 \mathrm{~km}$ east of Harare, flows in an east-west direction until reaching the Great Dyke, after which it flows in a northerly direction until it reaches Lake Cahora Bassa on the Zambezi River in Mozambique. The upper Manyame is of great importance because it supplies water to Harare and Chitungwiza, and some smaller centres such as Norton and Ruwa, which together have a population of about 2 million people or $18 \%$ of Zimbabwe's population (Magadza, 1997). Four dams have been constructed on the river to meet these needs, while another dam has recently been built on the Manyame about $100 \mathrm{~km}$ from Harare near the town of Chinhoyi (Fig. 1). These impoundments range in size from 215 to 8100 ha (Table 1) and all are susceptible to some degree to pollution emanating from the Harare urban area.

Harava (formerly Henry Hallam) Dam is located $15 \mathrm{~km}$ south of Harare at the junction of the Manyame and Ruwa Rivers. When Robarts and Southall (1977) examined nutrient limitation in this impoundment, its catchment area was predominantly rural and there was no evidence of nutrient enrichment.

\begin{tabular}{|c|c|c|c|c|c|}
\hline \multicolumn{6}{|c|}{$\begin{array}{l}\text { Table } 1 \\
\text { Physical characteristics of the } 5 \text { impoundments on the } \\
\text { Manyame River. Data from Marshall (1994) and Zimbabwe } \\
\text { National Water Authority. }\end{array}$} \\
\hline \multicolumn{2}{|c|}{ Date of construction } & $\begin{array}{r}\text { Area } \\
\text { (ha) }\end{array}$ & $\begin{array}{c}\text { Volume } \\
\left(m^{3} \times 10^{6}\right)\end{array}$ & $\begin{array}{c}\text { Mean } \\
\text { depth }(m)\end{array}$ & $\begin{array}{l}\text { Catchment } \\
\text { area }\left(\mathbf{k m}^{2}\right)\end{array}$ \\
\hline Harava & 1973 & 215 & 9 & 4.3 & 149 \\
\hline Seke & 1929 & 109 & 4 & 3.3 & 748 \\
\hline Chivero & 1952 & 2630 & 250 & 9.5 & 2227 \\
\hline Manyame & 1976 & 8100 & 480 & 6.0 & 3790 \\
\hline Bhiri & 2000 & 112 & 172 & 3.2 & 5362 \\
\hline
\end{tabular}

Since then, the population has grown rapidly with an expansion of the semi-formal settlement of Epworth and the townships of Mabvuku and Ruwa, and there may now be much higher levels of nutrient enrichment in the dam. Evidence that this may be occurring can be seen in the extensive growth of Eichhornia natans on the dam, although it does not form mats because its water level fluctuates extensively and it is exposed to the wind.

Seke (formerly Prince Edward) Dam is located immediately below Harava Dam, which spills almost directly into its upper end. There was no evidence of nutrient enrichment in the 1970s (Robarts and Southall, 1977) but this could have changed, since all of its water comes from Harava Dam and it may also have been affected by population growth in the catchment area. This is supported by the fact that much of its water surface is now covered by macrophytes, principally Eichhornia natans, Hydrocotyle ranunculoides, Nymphaea sp. and Azolla filiculoides.

Lake Chivero is the next impoundment downstream, located about $35 \mathrm{~km}$ southwest of the city of Harare. It was created as the principal water supply for the city and has a long history of water quality problems caused by the discharge of sewage effluent from Harare and Chitungwiza into its tributaries, most evident as algal blooms and problems with floating macrophytes such as the water hyacinth Eichhornia crassipes (Marshall, 2005). The lake has been enriched to the extent that phosphorus is no longer a limiting nutrient and the phytoplankton may now be self-limiting through reduced light penetration caused by its dense population (Robarts 1981, Robarts and Southall, 1975, 1977; Robarts et al., 1982). Its water quality improved briefly in 
the 1970s following a programme to divert sewage effluent onto the land for irrigation, but this was insufficient to deal with the increasing quantities of effluent and the water quality continued to deteriorate from the mid-1980s onwards.

Lake Manyame was created in 1976 with the construction of the Darwendale Dam about $15 \mathrm{~km}$ below Lake Chivero. Although most of its inflow comes from Lake Chivero it is not yet exhibiting effects of eutrophication, although there is some evidence of elevated phosphorus concentrations (Marshall, 1994) and the dense growth of Lagarosiphon ilicifolius that occurs in shallow areas may be an early symptom of enrichment. The growth of the town of Norton, situated on the south bank, has been rapid in recent years and may cause problems in future. Little research has been done on this lake, apart from a description of temperature and oxygen stratification in its formative years (Cotterill and Thornton, 1985).

Bhiri Dam, the most recently-constructed dam in the catchment, was created to supply irrigation water, although it has not been fully utilised for this purpose. Like other dams in the area it was probably eutrophic during its filling phase owing to the release of nutrients from the drowned land and vegetation (Coche, 1974; Mitchell and Marshall, 1974; Masundire, 1992). Its nutrient status is presently unknown but the presence of extensive beds of Lagarosiphon ilicifolius suggests that it may still be enriched.

\section{Methods}

The 6 sites in the 5 impoundments were sampled from November 2004 to February 2005. Sampling sites in Harava Dam, Seke Dam and Lake Chivero were the same as those used in 1975-76 (Robarts and Southall, 1977). In Harava Dam, samples were taken from each of the arms of the impoundment formed by the 2 inflowing rivers, the Manyame (sampling station located at $\left.17^{\circ} 60^{\prime} \mathrm{S} 31^{\circ} 03^{\prime} \mathrm{E}\right)$ and the Ruwa $\left(17^{\circ} 58^{\prime} \mathrm{S} 31^{\circ} 02^{\prime} \mathrm{E}\right)$. The sampling point in Seke Dam was located about $150 \mathrm{~m}$ from the dam wall ( $\left.17^{\circ} 59^{\prime} \mathrm{S} 31^{\circ} 03^{\prime} \mathrm{E}\right)$, mid-lake. The sampling sites in Lake Chivero, Lake Manyame and Bhiri Dam were located in deep waters in the main part of the dams at $17^{\circ} 55^{\prime} \mathrm{S} 30^{\circ} 49^{\prime} \mathrm{E}, 20^{\circ}$ $13^{\prime} \mathrm{S} 32^{\circ} 11^{\prime} \mathrm{E}$ and $17^{\circ} 49^{\prime} \mathrm{S} 30^{\circ} 31^{\prime} \mathrm{E}$, respectively. The following physico-chemical variables were measured with a Horiba U23 water quality monitor: dissolved oxygen, conductivity and $\mathrm{pH}$, with readings being taken from the surface to the bottom at 0.5 $m$ intervals. Transparency was determined with a Secchi disc. A Nansen water sampler was used to collect water samples at depths of $5 \mathrm{~m}$ and these samples were mixed to give an integrated sample, which was taken to the laboratory for analysis. The concentrations of ammonia, total nitrogen and total phosphorus were determined in the laboratory by using a HACH ER/04 water testing kit. A $20 \ell$ sample of depth integrated water was collected in a plastic container at each dam and transported to the laboratory for bioassay cultures.

Phytoplankton samples were collected by filtering $50 \ell$ of lake water through a $25 \mu \mathrm{m}$ plankton net and, after preservation in Lugol's solution, the species present were identified in the laboratory under an inverted microscope with the help of identification keys in Lund and Lund (1998) and Elenbaas (1994). The density of phytoplankton was determined by counting the numbers present in $5 \times 1-\mathrm{m} \ell$ sub-samples from each site and the mean value was recorded. An estimate of phytoplankton biomass was obtained by measuring chlorophyll $a$ and phytophytein using methods given in Bartram and Balance (1995).

Nutrient limitation in each impoundment was determined from bioassays with Selenestrum capricornutum as the test organism as well as by enrichment experiments using natural populations of phytoplankton. For the bioassays with Selenestrum capricornutum, surface water samples were filtered under reduced pressure through $1.2 \mu \mathrm{m}$ and $0.45 \mu \mathrm{m}$ membrane filters. Forty-five $100-\mathrm{m} \ell$ conical flasks were autoclaved and numbered permanently, then washed with filtered water from the samples, after which $60 \mathrm{~m} \ell$ of filtered water was introduced into each flask and nutrients added. Nutrient solutions were made up with various macro- and micronutrients (Table 2); for certain solutions some nutrients were left out so that bioassays were done on solutions lacking certain nutrients. A $1 \mathrm{m \ell}$ aliquot from a 1-week-old pure culture of Selenestrum capricornutum was added to each flask, which was then plugged loosely with cotton wool and covered with aluminium foil. The cultures were grown at room temperature. Growth was measured every 3 days, over a period of 9 days, by the change in absorbance at $600 \mathrm{~nm}$ using a DR/2010 spectrophotometer. Absorbance was then converted to biomass $\left(\mathrm{mg} \cdot \ell^{-1}\right)$ :

$$
B=31.97+152.25 A_{600}, r^{2}=0.71
$$

where:

$$
\begin{aligned}
& B=\text { biomass } \\
& A_{600}=\text { absorbance at } 600 \mathrm{~nm}
\end{aligned}
$$

\begin{tabular}{|c|c|c|c|c|}
\hline \multicolumn{5}{|c|}{$\begin{array}{c}\text { Table } 2 \\
\text { Nutrient solutions and final enrichments of bioassay } \\
\text { cultures. All micronutrients were added as one solution } \\
\text { with a total volume of } 0.1 \mathrm{me} \text {. } \\
\text { (From: Robarts and Southall, 1977) }\end{array}$} \\
\hline & $\begin{array}{l}\text { Molarity } \\
\text { of stock } \\
\text { solution }\end{array}$ & 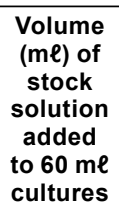 & \multicolumn{2}{|c|}{$\begin{array}{l}\text { Final enrichment } \\
\text { concentration } \\
\left(\mathrm{mg} \cdot \ell^{-1}\right)\end{array}$} \\
\hline \multicolumn{5}{|l|}{ (a) Macronutrients } \\
\hline \multirow{2}{*}{$\mathrm{NaNO}_{3}$} & \multirow{2}{*}{0.300} & \multirow{2}{*}{0.1} & $\mathrm{~N}$ & 6.80 \\
\hline & & & $\mathrm{Na}$ & 11.70 \\
\hline \multirow{2}{*}{$\mathrm{K}_{2} \mathrm{HPO}_{4}$} & \multirow{2}{*}{0.006} & \multirow{2}{*}{0.1} & $\mathrm{~K}$ & 0.76 \\
\hline & & & $P$ & 0.30 \\
\hline \multirow{2}{*}{$\mathrm{MgCl}_{2} \cdot 6 \mathrm{H}_{2} \mathrm{O}$} & \multirow{2}{*}{0.028} & \multirow{2}{*}{0.1} & $\mathrm{Mg}$ & 1.10 \\
\hline & & & $\mathrm{Cl}$ & 3.21 \\
\hline \multirow{2}{*}{$\mathrm{MgSO}_{4} \cdot 7 \mathrm{H}_{2} \mathrm{O}$} & \multirow{2}{*}{0.055} & \multirow{2}{*}{0.1} & $\mathrm{Mg}$ & 2.16 \\
\hline & & & $\mathrm{S}$ & 2.86 \\
\hline \multirow{2}{*}{$\mathrm{CaCl}_{2} \cdot 2 \mathrm{H}_{2} \mathrm{O}$} & \multirow{2}{*}{0.030} & \multirow{2}{*}{0.1} & $\mathrm{Ca}$ & 1.95 \\
\hline & & & $\mathrm{Cl}$ & 3.44 \\
\hline \multirow{2}{*}{$\mathrm{NaHCO}_{3}$} & \multirow{2}{*}{0.179} & \multirow{2}{*}{0.1} & $\mathrm{Na}$ & 6.67 \\
\hline & & & $\mathrm{C}$ & 3.48 \\
\hline \multicolumn{5}{|l|}{ (b) Micronutrients } \\
\hline $\mathrm{H}_{3} \mathrm{BO}_{3}$ & 0.003 & \multirow{8}{*}{0.1} & B & 0.053 \\
\hline $\mathrm{MnCl}_{2} \cdot 4 \mathrm{H}_{2} \mathrm{O}$ & 0.001 & & $\mathrm{Mn}$ & 0.119 \\
\hline $\mathrm{ZnCl}_{2}$ & 0.0002 & & $\mathrm{Zn}$ & 0.025 \\
\hline $\mathrm{Na}_{2}$ EDTA.H $\mathrm{H}_{2} \mathrm{O}$ & 0.00003 & & Mo & 0.005 \\
\hline $\mathrm{FeCl}_{3} \cdot 6 \mathrm{H}_{2} \mathrm{O}$ & 0.00036 & & $\mathrm{Fe}$ & 0.032 \\
\hline $\mathrm{Na}_{2}$ EDTA. $2 \mathrm{H}_{2} \mathrm{O}$ & 0.0008 & & EDTA & 0.376 \\
\hline $\mathrm{CoCl}_{2} \cdot 6 \mathrm{H}_{2} \mathrm{O}$ & 0.00003 & & $\mathrm{Co}$ & 0.003 \\
\hline $\mathrm{CuCl}_{2}$ & 0.0000007 & & $\mathrm{Cu}$ & 0.00007 \\
\hline
\end{tabular}

This equation was obtained by growing Selenestrum capricornutum in cultures, measuring the absorbance and then filtering 
the culture through previously weighed filter paper, drying the filter paper and residue in an oven at $105^{\circ} \mathrm{C}$. The dry weight of Selenastrum on the filter paper was then determined by subtraction.

Water for enrichment experiments was collected by filtering $20 \ell$ of dam water through a $20 \mu \mathrm{m}$ mesh plankton net to remove the zooplankton. The water was taken to the laboratory in a plastic container where the following treatments were prepared in triplicate in transparent bottles of about $1 \ell$ volume: (i) all nutrients supplied except $\mathrm{K} P \mathrm{PO}_{4}$, (ii) all nutrients except $\mathrm{NaNO}$, (iii) all nutrients except micronutrients, (iv) all nutrients and (v) no nutrients. A $5 \mathrm{ml}$ aliquot of phytoplankton collected by filtering $20 \ell$ of lake water through a $25 \mu \mathrm{m}$ plankton net was added to each bottle. The treatments were incubated at $21^{\circ} \mathrm{C}$ using natural light and the growth of the phytoplankton community was determined by measuring the chlorophyll $a$ concentration after 1, 2 and 3 days according to the method given in Bartram and Balance (1995). Each experiment was replicated 3 times.

\section{Data analysis}

A 1-way analysis of variance (ANOVA) was used to test variation in the physico-chemical variables and phytoplankton biomass among the dams. T-tests were used to ascertain if there was a change in the pattern of nutrient limitation since 1974-75 in the impoundments studied by Robarts and Southall (1977). The t-test was also used to determine if the physico-chemical variables in the 2 arms of Harava Dam were significantly different. The Brillouin index of diversity was used to measure the diversity of phytoplankton in each dam using the equation:

$$
H B=\left\{\operatorname{In} N !-a ̊ \operatorname{In} n_{y}\right\} / N i
$$

where:

$$
\begin{aligned}
& H B=\text { index of species diversity } \\
& N=\text { total number of individuals in a sample } \\
& n_{i} \quad=\text { number of individuals of } i \text { th species }
\end{aligned}
$$

Cluster analysis was carried out on physico-chemical variables and algal composition to group dams with similar water quality.

\section{Results}

\section{Trophic status of the $\mathbf{5}$ impoundments}

All variables, except for dissolved oxygen, followed a similar trend of increasing in concentration from Harava Dam to Lake Chivero and then decreasing from Lake Chivero to Bhiri Dam. This reflects the eutrophic status of Lake Chivero and the generally mesotrophic status of the other water bodies.

The mean $\mathrm{pH}$ ranged from 5.1 in Bhiri Dam to 8.9 in Lake Chivero and, although it was higher in Harava and Seke dams (6.8 and 7.1, respectively), it was much lower in Lake Manyame and Bhiri Dam (5.6 and 5.1, respectively). Nevertheless, $\mathrm{pH}$ in Harava, Seke, Lake Manyame and Bhiri Dams was not significantly different (ANOVA, $p>0.05)$. The $\mathrm{pH}($ mean $=8.9)$ was significantly higher in Lake Chivero (ANOVA, $p<0.05$ ) than in the other impoundments, which reflects its eutrophic state.

Conductivity ranged from 229 to $331 \mu \mathrm{S} \cdot \mathrm{cm}^{-1}$, with the lowest values in Harava and Seke Dams. It rose sharply in Lake Chivero and remained relatively high in the 2 downstream impoundments (Lake Manyame and Bhiri Dam), with conductivities for all 3 downstream water bodies being significantly

\begin{tabular}{|l|l|}
\hline \multicolumn{2}{|c|}{$\begin{array}{c}\text { Table } 3 \\
\text { The growth cultures used in the bioassays. } \\
\text { (From: Robarts and Southall,1977) }\end{array}$} \\
\hline Culture & \\
\hline 1 & All nutrients added except $\mathrm{NaNO}_{3}$ \\
\hline 2 & All nutrients added except $\mathrm{K}_{2} \mathrm{HPO}_{4}$ \\
\hline 3 & All nutrients added except $\mathrm{MgCl}_{2} \cdot 6 \mathrm{H}_{2} \mathrm{O}$ \\
\hline 4 & All nutrients added except $\mathrm{MgSO}_{4} \cdot 7 \mathrm{H}_{2} \mathrm{O}$ \\
\hline 5 & All nutrients added except $\mathrm{CaCl}_{2} \cdot 2 \mathrm{H}_{2} \mathrm{O}$ \\
\hline 6 & All nutrients added except $\mathrm{CaCl}_{2} \cdot 2 \mathrm{H}_{2} \mathrm{O}$ \\
\hline 7 & All nutrients added except $\mathrm{micronutrients}^{2}$ \\
\hline 8 & No nutrient enrichment \\
\hline
\end{tabular}

higher (ANOVA, $p<0.05$ ) than conductivities recorded in the upper 2 impoundments (Seke and Harava Dams).

The 2 arms of Harava (Ruwa and Manyame arm) and Seke Dams were too shallow to develop an oxycline, with a secchi depth of $0.9 \mathrm{~m}, 1.1 \mathrm{~m}$ and $1.5 \mathrm{~m}$, respectively, although the concentration of dissolved oxygen decreased below the depth of the photic zone. Oxygen concentrations were very high in the first metre of Lake Chivero and decreased continuously below the photic zone, falling to $4.7 \mathrm{mg} \cdot \ell^{-1}$ at $14 \mathrm{~m}$ but without a marked oxycline, and with a secchi depth of $0.7 \mathrm{~m}$. Oxygen concentrations were not as high in Lake Manyame, which had a transparency of $2.5 \mathrm{~m}$, and only began to decline from $3 \mathrm{~m}$ downwards, but there was no oxycline because the lake was too shallow. Transparency was highest in Bhiri Dam $(5 \mathrm{~m})$ and dissolved oxygen concentrations were $>7.0 \mathrm{mg} \cdot \ell^{-1}$ down to $4 \mathrm{~m}$ depth, which marked the beginning of a pronounced oxycline with the concentration of dissolved oxygen falling to $0.3 \mathrm{mg} \cdot \ell^{-1}$ at $8 \mathrm{~m}$ depth.

The eutrophic state of Lake Chivero was most clearly demonstrated in the concentrations of ammonia (Fig. 2a), total nitrogen (Fig. 2b) and total phosphorus (Fig. 2c), which were much higher than in any of the other impoundments. The concentrations of these nutrients were significantly lower in these impoundments (ANOVA, $p<0.05$ ) than in Lake Chivero, but they were not significantly different from each other ANOVA, $p>0.05$ ).

\section{Nutrient limitation}

According to the bioassays with Selenastrum capricornutum, nitrogen is the primary limiting nutrient in both arms of the Harava Dam, Lake Manyame and Seke Dam, phosphorus was the limiting nutrient in Bhiri Dam and no nutrient was limiting in Lake Chivero (Fig. 3). Sulphur is the secondary limiting nutrient in both arms of Harava and Seke Dams while phosphorus and nitrogen were the secondary limiting nutrients in Lake Manyame and Bhiri Dam respectively.

Trends in the results of the bioassay with the lake's phytoplankton community are less obvious (Fig. 4). In both arms of the Harava Dam nitrogen seemed to be the main limiting nutrient, while in Seke Dam phosphorus was rather more limiting. There was no nutrient limitation in Lake Chivero but both nitrogen and phosphorus limited growth to some extent in Lake Manyame. Phosphorus is the primary limiting nutrient in Bhiri Dam.

\section{Phytoplankton biomass and generic composition}

The biomass of phytoplankton was not significantly different (ANOVA, $p>0.05$ ) in the impoundments $\left(12-17 \mathrm{mg} \cdot \mathrm{m}^{-3} \mathrm{dry}\right.$ 


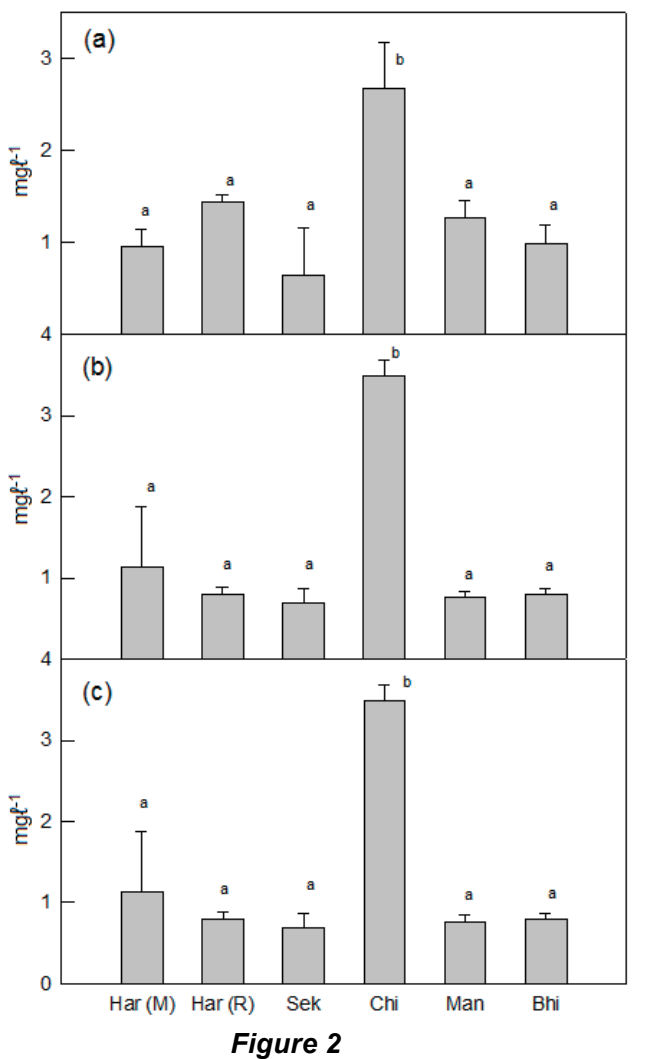

The mean values of (a) ammonia, (b) nitrogen and (c) phosphorus in the five impoundments Values with the same superscripts are not significantly different (ANOVA, $p>0.05$ )
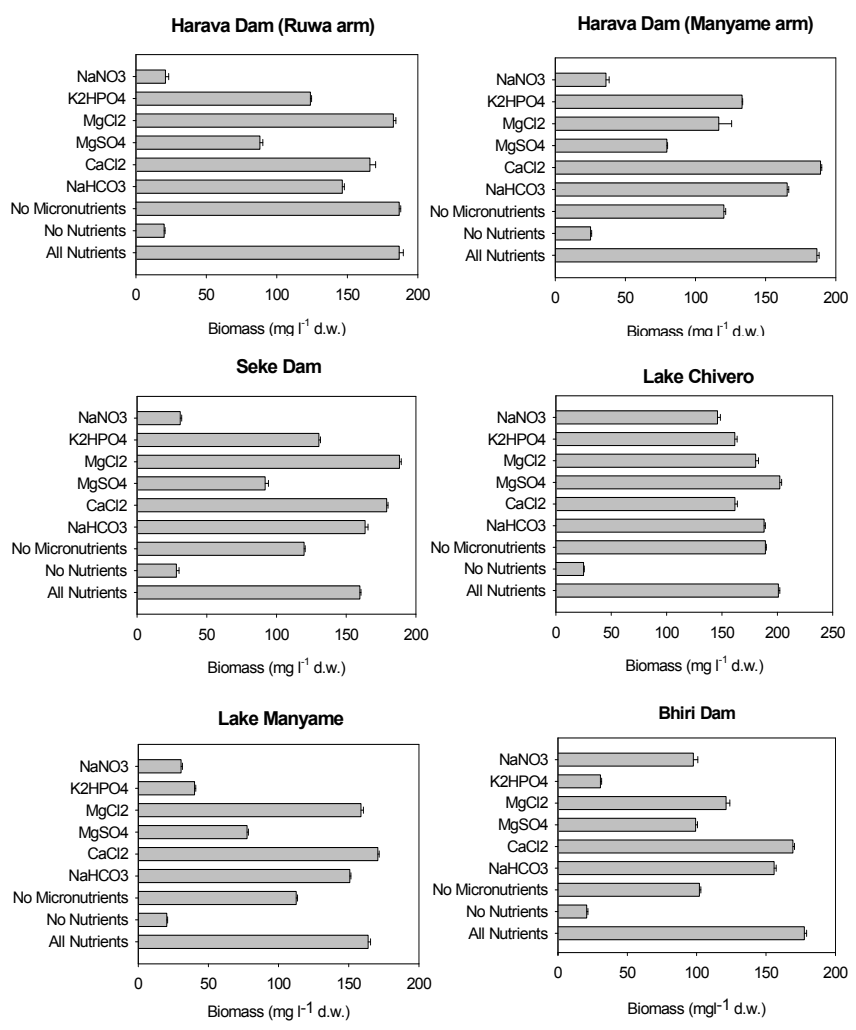

Figure 3

The mean maximum growth response $\left(m g \cdot \ell^{-1} d r y\right.$ weight) of Selenestrum capricornutum after nine days of incubation in membrane filtered lake water with different nutrient enrichments
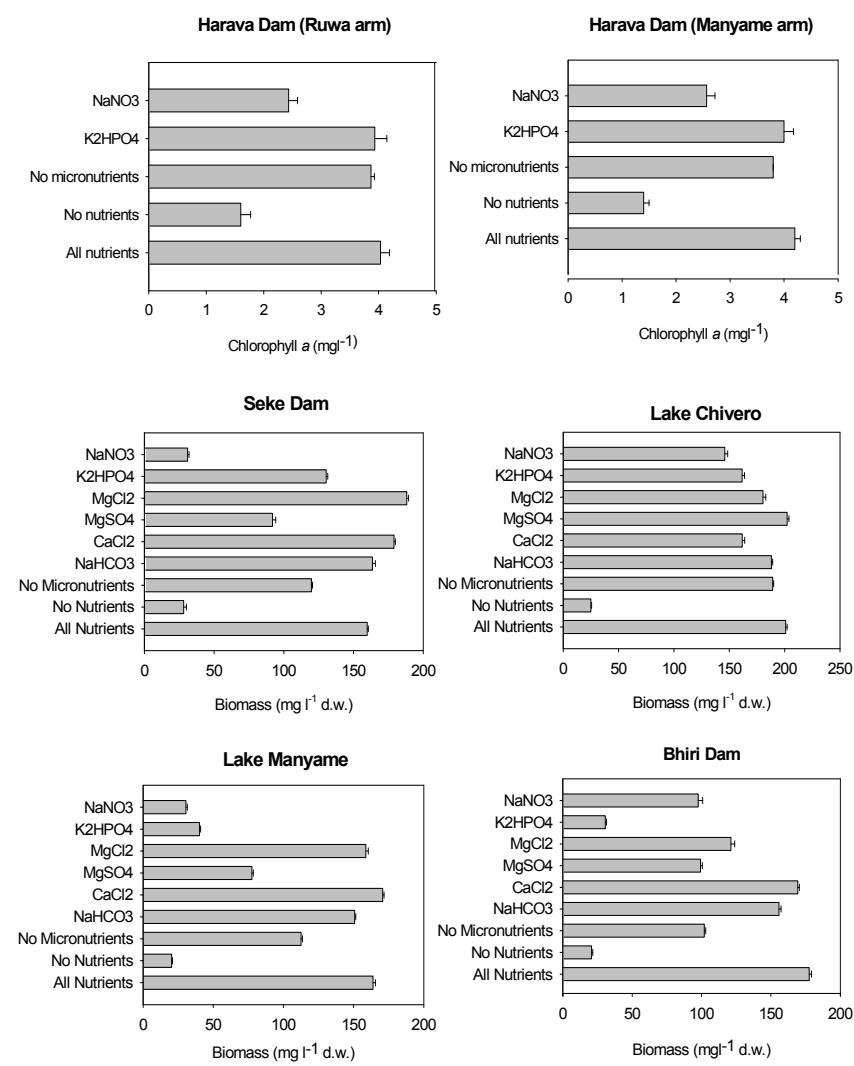

Figure 4

Mean maximum growth response of phytoplankton community after three days of incubation in filtered lake water with different nutrient enrichments

weight), except for Lake Chivero where it was much higher $\left(38 \mathrm{mg} \cdot \mathrm{m}^{-3}\right)$ than in the others, which is a reflection of its eutrophic state.

A total of 41 genera were identified from the phytoplankton samples with the largest number (38) being recorded in Lake Chivero, followed by Bhiri Dam, with 29 genera (Table 4). Blue-green algae were the dominant type of algae, making up from $61 \%$ of the total in the Manyame arm of Harava Dam to $89 \%$ in Lake Manyame. Microcystis was the most abundant form constituting 61\% (Manyame arm of Harava Dam) to $80 \%$ in Lake Manyame. Blue-greens were the second-most numerous forms in the Ruwa arm of Harava Dam and Lake Manyame (Oscillatoria), and Lake Chivero and Seke Dam (Anabaena). Bhiri Dam differed slightly in having green algae, Pediastrum as the second-most numerous form, while the Manyame arm of Harava Dam differed further in having the dinoflagellate Ceratium as the second-most numerous form ( $24 \%$ of the total). The Brillouin diversity index differed little amongst the impoundments, ranging from 1.06 (Lake Manyame) to 1.47 (Seke Dam).

Using algal composition in the respective dams, the 5 impoundments were classified by cluster analysis into 3 groups (Fig. 5). Harava Dam, Seke Dam and Lake Manyame were showed to be similar to each other while Lake Chivero and Bhiri were different from the other dams. Using physico-chemical variables, the impoundments were clustered into 3 groups with Bhiri Dam and Lake Manyame in one group, Harava Dam and Seke Dam in the other, while Lake Chivero constituted the last group. 


\begin{tabular}{|c|c|c|c|c|c|c|c|}
\hline \multicolumn{8}{|c|}{$\begin{array}{c}\text { Table } 4 \\
\text { The composition of the phytoplankton in the } 5 \text { impoundments (abundance per } 1 \text { me } \\
\text { sample) }\end{array}$} \\
\hline \multirow[t]{2}{*}{$\begin{array}{l}\text { Date of } \\
\text { collection }\end{array}$} & \multirow[t]{2}{*}{ Genera } & $\begin{array}{l}\text { Harava } \\
\text { (Ruwa) }\end{array}$ & $\begin{array}{c}\text { Harava } \\
\text { (Manyame) }\end{array}$ & Seke Dam & $\begin{array}{c}\text { Lake } \\
\text { Chivero }\end{array}$ & $\begin{array}{c}\text { Lake } \\
\text { Manyame } \\
\end{array}$ & $\begin{array}{l}\text { Bhiri } \\
\text { Dam }\end{array}$ \\
\hline & & $10-11.04$ & $11-11-04$ & 17-11-04 & 30-11-04 & 27-01-05 & 09-02-05 \\
\hline \multirow{17}{*}{ Chlorophyta } & Pediastrum & 18 & 8 & 10 & 35 & 31 & 28 \\
\hline & Scenedesmus & 5 & 0 & 0 & 21 & 0 & 3 \\
\hline & Volvox & 18 & 4 & 12 & 19 & 18 & 21 \\
\hline & Chlamydomonas & 6 & 0 & 0 & 44 & 19 & 23 \\
\hline & Eudirina & 0 & 0 & 0 & 11 & 0 & 2 \\
\hline & Ankistrodesmus & 0 & 0 & 0 & 12 & 0 & 0 \\
\hline & Spirigyra & 41 & 24 & 4 & 27 & 23 & 5 \\
\hline & Straurastrum & 0 & 28 & 60 & 71 & 12 & 3 \\
\hline & Zygnema & 0 & 0 & 0 & 3 & 1 & 5 \\
\hline & Chlorella & 8 & 0 & 0 & 16 & 0 & 0 \\
\hline & Coelastrum & 0 & 0 & 0 & 1 & 0 & 0 \\
\hline & Pandorina & 108 & 0 & 0 & 2 & 3 & 0 \\
\hline & Gonium & 3 & 17 & 29 & 8 & 0 & 0 \\
\hline & \begin{tabular}{|l|} 
Selanastrum \\
\end{tabular} & 9 & 0 & 0 & 7 & 2 & 3 \\
\hline & Amscottia & 7 & 0 & 0 & 0 & 0 & 0 \\
\hline & Asterococcus & 20 & 92 & 0 & 41 & 0 & 0 \\
\hline & Unidentified & 5 & 0 & 1 & 0 & 0 & 0 \\
\hline \multirow{9}{*}{ Bacillariophyta } & Asterionella & 19 & 18 & 21 & 2 & 17 & 5 \\
\hline & Melosira & 82 & 0 & 0 & 47 & 7 & 2 \\
\hline & Navicula & 0 & 0 & 47 & 19 & 0 & 1 \\
\hline & Pinnilaria & 2 & 0 & 80 & 75 & 8 & 2 \\
\hline & Cyclotella & 3 & 22 & 19 & 55 & 4 & 12 \\
\hline & Tabellaria & 11 & 40 & 0 & 2 & 14 & 21 \\
\hline & Gyrosigma & 0 & 0 & 81 & 0 & 0 & 1 \\
\hline & \begin{tabular}{|l|} 
Sirirella \\
\end{tabular} & 0 & 0 & 78 & 80 & 0 & 1 \\
\hline & Synedra & 0 & 0 & 0 & 1 & 1 & 2 \\
\hline \multirow{8}{*}{ Cyanophyta } & Microcystis & 1675 & 962 & 1264 & 2985 & 1288 & 524 \\
\hline & Anabaena & 13 & 9 & 89 & 93 & 24 & 12 \\
\hline & Spirulina & 0 & 3 & 0 & 7 & 19 & 13 \\
\hline & Nostoc & 0 & 0 & 0 & 3 & 0 & 2 \\
\hline & Oscillatoria & 158 & 51 & 47 & 43 & 38 & 21 \\
\hline & Unidentified & 0 & 0 & 2 & 1 & 0 & 1 \\
\hline & Chroococcus & 0 & 0 & 0 & 1 & 29 & 11 \\
\hline & Merismopedia & 0 & 0 & 4 & 56 & 26 & 10 \\
\hline \multirow{3}{*}{ Euglenophyta } & Phacus. & 1 & 0 & 0 & 2 & 5 & 1 \\
\hline & Euglena $\mathrm{sp}$ & 2 & 0 & 0 & 23 & 3 & 2 \\
\hline & Traachelomonas & 0 & 0 & 0 & 1 & 0 & 0 \\
\hline Dinophyta & Ceratium & 0 & 411 & 39 & 2 & 12 & 3 \\
\hline \multirow{3}{*}{ Haptophyta } & Rhodomonas & 0 & 0 & 0 & 1 & 0 & 0 \\
\hline & Gonyostomum & 0 & 0 & 71 & 0 & 0 & 0 \\
\hline & Rotifera & 1 & 1 & 0 & 0 & 2 & 0 \\
\hline \multicolumn{2}{|l|}{ Total } & 2215 & 1690 & 1958 & 3817 & 1606 & 740 \\
\hline \multicolumn{2}{|l|}{ No. of genera } & 23 & 15 & 18 & 36 & 24 & 29 \\
\hline \multicolumn{2}{|c|}{ Brillouin diversity index } & 1.10 & 1.32 & 1.47 & 1.31 & 1.06 & 1.43 \\
\hline
\end{tabular}

growth in the bioassay is not limited by any nutrients (Table 5). The transparency in the lake is low and it is likely that productivity may now be limited by light, as it was in the 1970s (Robarts, 1979; Robarts et al., 1982).

The key questions being addressed in this investigation were whether or not the Harava and Seke Dams had become more eutrophic in the 30 years since Robarts and Southall (1977) worked in them. The likelihood that they may have become enriched has been increased because of the rapid urbanisation of the Ruwa River catchment, which now includes at least 2 sewage works. Since the Manyame River drains a largely rural catchment the 2 arms of the Harava Dam might be expected to be different but this has not been the case, with no significant differences recorded in their physicochemical status. The only notable biological difference between them was the much lower phytoplankton density and lower proportion of blue-green algae in the Manyame arm. This arm was unusual in having a high proportion of Ceratium in its phytoplankton, common in waters relatively rich in plant nutrients such as nitrates and phosphates (Lund and Lund, 1995), but whether this reflects differences in water quality is unclear.

The eutrophic status of these impoundments was also determined by examining the differences between the Selenastrum capricornutum bioassays done 30 years ago and those conducted in the present study. The most significant differences in growth response occurred when no nutrients were added and when no phosphorus was added (Table 5). The 15- to 17-fold increase in the growth response without the addition of phosphorus suggests that

\section{Discussion}

The most distinctive feature of the 5 impoundments was the highly eutrophic state of Lake Chivero. The lake has been in this state since the 1960s (Munro, 1966) and is likely to remain so because the local authorities responsible for sewage treatment have not been able to keep up with the population growth in Harare and Chitungwiza (Marshall, 2005). Lake Chivero's eutrophic condition is reflected in all physio-chemical variables and by a much higher density and biomass of phytoplankton than in the other impoundments, and by the fact that algal this nutrient no longer limits algal growth in either the Harava or Seke Dams. This was confirmed by the bioassays, which indicated that nitrogen is now the main limiting nutrient, a situation quite different from that prevailing in the 1970s when phosphorus was limiting (Robarts and Southall, 1977). The switch from $\mathrm{N}$-limitation to P-limitation is generally an indication of enrichment in Southern Africa, where the soils tend to be deficient in phosphorus, while nitrogen deficiencies can be made up though nitrogen fixation by blue-green algae (Thornton, 1980)

A second important question was whether or not the 


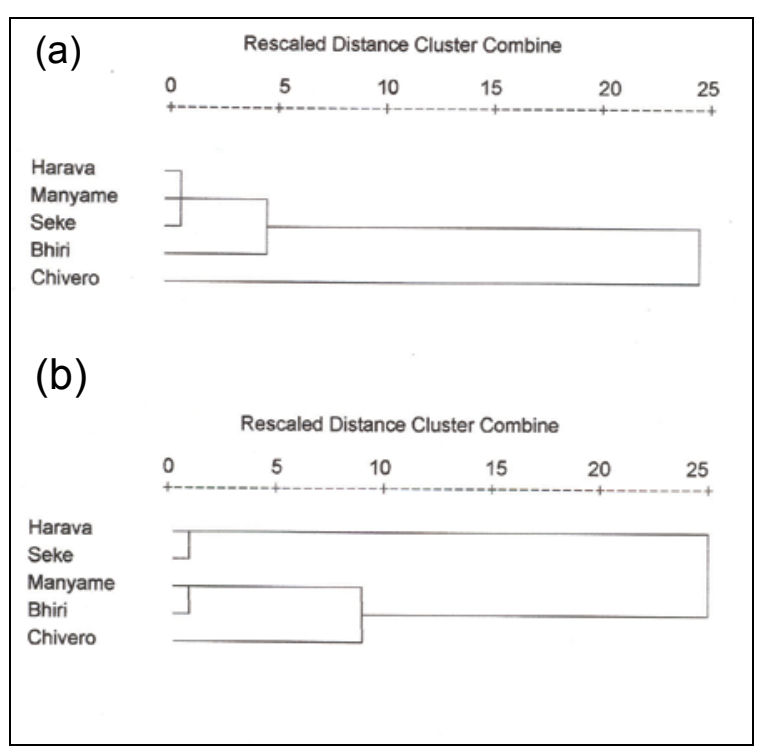

Figure 5

The relationships among the five impoundments based on a cluster analysis of

(a) Algal composition and (b) Physico-chemical variables

impoundments below Lake Chivero were being enriched by the discharge of nutrient-rich water from the lake. These impoundments downstream have not yet become eutrophic and Lake Chivero is therefore acting as a nutrient trap. Conductivity seems to be an exception to this general trend because it was high in both Lake Manyame and Bhiri Dam. This suggests that water from Lake Chivero was affecting these impoundments, although this is contradicted by the decrease in calcium and chloride in the 2 lower impoundments. One possible explanation for the high conductivity in Lake Manyame and Bhiri Dam is that they both receive water from the Great Dyke, a unique geological feature consisting of mafic and ultramafic rocks such as norite, pyroxenite and serpentine (Worst, 1960). The streams originating on the dyke have an unusually high concentration of magnesium (Harrison et al., 1966) and this might explain the high conductivity of the 2 lower impoundments.

The bioassays with Selenastrum capricornutum showed that productivity in Lake Chivero, as in the study by Robarts and Southall (1977), is limited by light rather than by any nutrient. This suggestion is supported by the low transparency of the lake. Phosphorus is commonly the limiting nutrient in southern African inland waters (Thornton and Walmsley, 1982; Allanson et al.,1990) and was the limiting nutrient in the Harava and Seke Dams in the 1970s (Robarts and Southall, (1977). The fact that it is no longer the limiting nutrient in these dams and Lake Manyame suggests that they have been enriched to some extent but are not yet eutrophic. The discharge of sewage effluent into the Ruwa River by the growing urban areas of Ruwa and Epworth probably accounts for the enrichment of Harava and Seke Dams and the situation may have been worse were it not for the fact that they are relatively small and have a low water retention time, which means that nutrients would be flushed out every rainy season when the dams overflow.

Lake Manyame, a lake reported to be mesotrophic by Watts (1982), is at risk from the growth of Norton and the western suburbs of Harare. Bhiri Dam is the only one that seemed to be oligotrophic, with phosphorus as the limiting nutrient. Paradoxically, it is the only dam with an anoxic hypolimnion, a feature normally associated with eutrophic conditions. However, larger reservoirs in Zimbabwe have an anoxic hypolimnion, regardless of their trophic status, and deoxygenation of deeper waters is particularly associated with new impoundments (Coche, 1974; Mitchell and Marshall, 1974; Masundire, 1992; Donnelly and Marshall, 2004).

The contradictory results between the bioassays with the lake's phytoplankton and those with Selenastrum capricornutum for Seke Dam could have been caused by the species composition of the inoculums, where the presence of one species can deplete one nutrient and that nutrient becomes depleted first, even if it is not limiting the growth of the whole phytoplankton community. Similar observations were made by Boyd et al. (1998).

The dominance of Microcystis and other blue-green algae in all of the impoundments was unexpected because this suggests that they might all be enriched, since most oligotrophic Zimbabwean reservoirs are dominated by green algae. There has been a change in the dominant algae of the Ruwa and Manyame arms of Harava Dam, Seke Dam and Lake Chivero over the last 30 years. Unlike in the 1974-75 study by Robarts and Southall (1977), Microcystis was the dominant genera at all 6 sites in the present study although at least one genus has maintained its dominance in each: Melosira in the Ruwa arm, Ceratium in the Manyame arm and Seke Dam, Microcystis and Anabaena in Lake Chivero.

The cluster analysis (Fig. 5(a)) indicated that the algal composition in Lake Manyame, Seke Dam and Harava Dam was generally similar, while Lake Chivero and Bhiri Dam were in groups on their own. The physico-chemical variables (Fig. 5(b)) grouped Seke and Harava Dams into one group, Lake Manyame

\begin{tabular}{|c|c|c|c|c|c|c|c|c|}
\hline \multicolumn{9}{|c|}{$\begin{array}{c}\text { Table } 5 \\
\text { The mean maximum growth response (expressed as } \mathrm{mg} \cdot \ell^{-1} \text { of chlorophyll a) of Selenestrum capricornutum } \\
\text { after } 9 \text { days of incubation in membrane-filtered lake water with different nutrient enrichments in 1974-75 } \\
\text { (Robarts and Southall, 1977) and 2004-05 (the present study) }\end{array}$} \\
\hline & \multicolumn{2}{|c|}{ Harava (Ruwa) } & \multicolumn{2}{|c|}{ Harava (Manyame) } & \multicolumn{2}{|c|}{ Seke Dam } & \multicolumn{2}{|c|}{ Lake Chivero } \\
\hline & 1974-75 & 2004-05 & 1974-75 & 2004-05 & 1974-75 & \begin{tabular}{|l|}
$2004-05$ \\
\end{tabular} & $1974-75$ & 2004-05 \\
\hline All nutrients & 162 & 186 & 170 & 186 & 148 & 159 & 175 & 201 \\
\hline No nutrients & 4 & 20 & 5 & 25 & 4 & 28 & 6 & 25 \\
\hline No micronutrients & 170 & 186 & 100 & 120 & 75 & 119 & 145 & 189 \\
\hline $\mathrm{No} \mathrm{NaHCO}_{3}$ & 125 & 146 & 150 & 165 & 145 & 163 & 170 & 188 \\
\hline $\mathrm{No} \mathrm{CaCl}_{2}$ & 150 & 166 & 160 & 189 & 150 & 179 & 165 & 161 \\
\hline $\mathrm{No} \mathrm{MgSO}_{4}$ & 75 & 88 & 60 & 79 & 75 & 91 & 175 & 202 \\
\hline${\mathrm{No} \mathrm{MgCl}_{2}}_{2}$ & 160 & 182 & 90 & 116 & 155 & 188 & 160 & 180 \\
\hline $\mathrm{No} \mathrm{K}_{2} \mathrm{HPO}_{4}$ & 8 & 123 & 6 & 133 & 7 & 130 & 16 & 161 \\
\hline $\mathrm{No} \mathrm{NaNO}_{3}$ & 12 & 21 & 11 & 36 & 15 & 31 & 5 & 146 \\
\hline
\end{tabular}


and Bhiri Dam into the other, with Lake Chivero in a group of its own. From these findings, the lakes can be classified into 3 distinct groups, oligotrophic (Bhiri Dam), mesotrophic (Harava Dam, Seke Dam and Lake Manyame) and eutrophic (Lake Chivero). The small sizes and shorter retention times of Harava and Seke Dam probably play a part in the nutrient status of the 2 dams and prevented them from becoming as eutrophic as Lake Chivero. As indicated, Lake Chivero seemed to be an effective nutrient trap but it can only continue doing so if its self-purification capacity is not exceeded. If it fails to retain nutrients, Lake Manyame, which is already showing signs of eutrophication, could be at risk of getting hyper-eutrophic.

This study has shown the importance of controlling nutrient inputs to Harare's reservoirs. Management options for the Manyame system should include reducing nutrient loading through more effective treatment of sewage, diversion of sewage effluent and other measures. At present local authorities are dealing with the symptoms of eutrophication, through water treatment, rather than dealing with its cause through better sewage treatment, which is likely to be more cost-effective in the long run. Unfortunately, Zimbabwe's economic decline is now so severe that the responsible authorities are very unlikely to find the resources to do this and the problem of eutrophication can be expected to become more severe.

\section{Acknowledgements}

I would like to thank my mentor Prof. Marshall for his guidance and constant encouragement in the undertaking of this study. A big thank you to the technical staff of University of Zimbabwe's Biological Sciences Department, for their support during the course of the study. This study was made possible by the financial support of VLIR/UZ project. I am truly grateful for all the resources that were made available to me.

\section{References}

ALLANSON BR, HART RC, O'KEEFFE JH and ROBARTS RD (1990) Inland Waters of Southern Africa: An Ecological Perspective. Kluwer Academic Publishers, Dordrecht. 458 pp.

BARTRAM J and BALANCE R (1995) Water Quality Monitoring. E \& FN Spon for UNEP \& WHO. 146-147.

BEARDALL J, YOUNG E and ROBERTS S ( 2001) Approaches for determining phytoplankton nutrient limitation. Aquat. Sci. 63 44-69.

BOYD P, BERGES JA and HARRISON PJ (1998) In vitro enrichment experiments at iron-rich and poor sites in the NE Subarctic Pacific. J. Exp. Mar. Biol. Ecol. 227 133-151.

COCHE AG (1974) Limnological study of a tropical reservoir. In: Balon EK and Coche AG (eds.) Lake Kariba: A Man Made Tropical Ecosystem in Central Africa. Monogr. Biol. 24 1-227.

COTTERILL NG and THORNTON JA (1985) Hydroclimate development following impoundment in a tropical African man-made lake (Lake Robertson, Zimbabwe). J. Limnol. Soc. S. Afr. 11 54-61.

Donnelly BG and Marshall BE (2004) The biology of Barbus mattozi Guimaraes (Teleostei, Cyprinidae) in a Zimbabwean reservoir. 3. Numbers, biomass and mortality. Afr. J. of Aq. Sci. 29 103-106.

GUILDFORD SJ, HECKY RE, TAYLOR WD, MUGIDDE R and BOOTSMA HA (2003) Nutrient enrichment experiments in tropical Great Lakes Malawi/Nyasa and Victoria. J. Great Lakes Res. 29 (Supplement 2) 89-106.

HAARHOFF J, LANGENEGGER O and VAN DER MERWE PJ (1992) Practical aspects of water treatment plant design for a hypertrophic impoundment. Water SA 18 27-36.
HARRISON AD, NDUKU W and HOOPER ASC (1966) The effects of a high magnesium-to-calcium ratio on the egg-laying rate of an aquatic planorbid snail, Biomphalaria pfeifferi. Ann. Trop. Med. Parasitol. $60212-214$

KUANG Q, BI Y, XIA Y and HU Z (2004) Phytoplankton community and algal growth potential in Taipinhu reservoir, Anhui Province, China. Lake Reserv. Manage. 9 119-124.

LUND HC and LUND JW (1998) Freshwater Algae - Their Microscopic World Explored. Biopress Ltd, Bristol.

MAGADZA CHD (1997) Water pollution and catchment management in Lake Chivero. In: Moyo NAG (ed.). Lake Chivero: A Polluted Lake. University of Zimbabwe Publications, Harare. 13-26.

MARSHALL BE (1994) Ecology and management of the Manyame lakes. In: Matiza T and Crafter SA (eds.) Wetlands Ecology and Priorities for Conservation in Zimbabwe. IUCN, Gland. 55-68.

MARSHALL BE (2005) The impact of eutrophication on Lake Chivero, Zimbabwe: a tropical African reservoir. In: Reddy MV (ed.) Restoration and Management of Tropical Eutrophic Lakes. Science Publishers, Enfield. 165-186.

MASUNDIRE HM(1992) The filling phase of Mazvikadei Reservoir, Zimbabwe. Hydrobiologia 232 11-17.

MITCHELL DS and MARSHALL BE (1974) Hydrobiological observations on three Rhodesian reservoirs. Freshwater Biol. 4 61-72.

MUNRO JL (1966) A limnological survey of Lake McIlwaine, Rhodesia. Hydrobiologia 28 281-308.

ROBARTS RD and SOUTHALL GC (1977) Nutrient limitation of phytoplankton growth in seven tropical man-made lakes, with special reference to Lake McIlwaine, Rhodesia. Arch. Hydrobiol. 79 1-35.

ROBARTS RD (1979) Underwater light penetration, chlorophyll $a$ and primary production in a tropical African lake (Lake McIlwaine, Rhodesia). Archiv für Hydrobiologie 86 423-444.

ROBARTS RD (1981) The phytoplankton. Zimb. Sci. News 15 95-96.

ROBARTS RD and SOUTHALLGC (1975) Algal bioassays of two tropical Rhodesian reservoirs. Acta Hydrochim. Hydrobiol. 3 369-377.

ROBARTS RD, THORNTON JA and WATTS CJ (1982) Phytoplankton, primary production and nutrient limitation. In: Thornton JA (ed.) Lake McIlwaine: The Eutrophication and Recovery of a Tropical African Lake. Dr W Junk Publishers, The Hague.

SCHINDLER DW, ARMSTRONG FA, HOLMGREN SK and BRUNSKILL GJ (1971) Eutrophication of Lake 227, Experimental Lakes area, Northwestern Ontario, by addition of phosphorus and nitrate. J. Fish. Res. Board Can. 28 1763-1782.

SCHINDLER DW (1977) The evolution of phosphorus limitation in lakes. Science 195 260-262.

THORNTON JA (1980) A review of limnology in Zimbabwe: 19591979. Ministry of Water Development and National Parks and Wildlife Management, Harare. National Water Quality Survey Report, Series No. 1. 86 36-42.

THORNTON JA and WALMSLEY RD (1982) Applicability of phosphorus budget models to southern African man-made lakes. Hydrobiologia 89 237-245.

UNEP (2000) Planning and Management of Lakes and Reservoirs: An Integrated Approach to Eutrophication. United Nations Environment Programme, Nairobi.

UNEP (2003) World Lake Vision: A Call to Action. World Lake Vision Committee.

VOLLENWEIDER RA (1992) Coastal marine eutrophication: principles and control. In: Vollenweider RA, Marchetti R and Viviani R (eds.) Marine Coastal Eutrophication, Science of the Total Environment Supplement. Elsevier, Amsterdam. 361-365.

WATTS CJ (1982) An examination of phytoplankton nutrient limitation in Lake McIlwaine and the Hunyani River system. In: Thornton JA (ed.). Lake McIlwaine: the Eutrophication and Recovery of a Tropical Lake. Dr. W. Junk, The Hague. 117-133.

WORST BG (1960) The Great Dyke of Southern Rhodesia. S. Rhod. Geol. Surv. Bull. 47234. 